\title{
Framework for Applicability of Agile Scrum Methodology: A Perspective of Software Industry
}

\author{
Anum Ali \\ Department of Computer Science \\ Lahore College for Women University, \\ Lahore, Pakistan
}

\author{
Mariam Rehman \\ Department of Computer Science \\ Lahore College for Women University, \\ Lahore, Pakistan
}

\author{
Maria Anjum \\ Department of Computer Science \\ Lahore College for Women University, \\ Lahore, Pakistan
}

\begin{abstract}
Agile scrum methodology has been evolved over the time largely through software industry where it has grown and developed through empirical progress. The research work presented in this paper has proposed a framework by identifying critical elements for applicability of agile scrum methodology in software industry. The proposed framework is based on four elements, i.e. technical, people, environmental and organizational. The proposed framework is validated through statistical analysis, i.e. Structural Equation Modeling (SEM) after collecting data from software industry personals who are working on agile methodologies. The research concludes that 15 out of 18 hypothesis were found significant which include Training \& Learning, Societal Culture, Communication \& Negotiation, Personal Characteristics, Customer collaboration, Customer commitment, Decision Time, Team Size, Corporate Culture, Planning, Control, Development, Information Administration, and Working Environment.
\end{abstract}

Keywords-Scrum agile methodology; framework; software industry; critical factors

\section{INTRODUCTION}

The main focus of agile methodology is customer satisfaction through continuous delivery. The use of agile method creates high quality product and environment [15]. In software development, scrum is an iterative methodology that depends on agile principles included in the Agile Manifesto [5], [18]. Moreover, Scrum is described as a light development method [8], [31] that provide complete insight, quick adaptability, working within small, dedicated autonomous and self-organized teams [4]. According to Sverrisdottir [25], Scrum has a strong position which can be defined in terms of visibility, effective process, fast development, roles, collaboration emphasis and understanding [26]. There are three parts of scrum teams which are scrum master, product owner and team member.

Companies have taken benefit from scrum because it enhances the quality and efficiency. Moreover, scrum is the mainstream of agile methodology in software industry. By adopting Scrum, organizations are getting more prominent benefit, collaboration, correspondence, participation of the development group, effectiveness, self-confidence among the improvement group and product management [7].

In this research, efforts have been made to address the following questions:
RQ1: What are the influencing factors for the applicability of agile scrum methodology from the perspective of software industry?

RQ2: Does there any framework exist in the literature for the applicability of agile scrum methodology?

The rest of the research paper is organized as: Section II provides background and motivation of this research. Section III describes analysis and identification of critical factors. Section IV explains proposed framework. Section V describes results and discussions. Finally, Section VI concludes research discussed in this paper.

\section{BACKGROUND AND MOTIVATION}

The literature available on agile scrum methodology and framework is limited to a few numbers of studies [1], [4], [12]. These studies include: Sincharoenpanich [12], Janeth LópezMartínez [10], Dyba and Dingsoyr [17], Cho and Juyun Joey [20], Qumer et al. [30], Vlietland and van Vliet [23], Moe [34], Rola [28], Lei et al. [11], Campanelli et al. [22], Sverrisdottir [25], Chan et al. [21], Misra et al. [35].

In Sincharoenpanich et al. [12], three factors were used for implementing scrum, i.e. organization, people and technical [33]. Organizations are enhancing the effectiveness and quality of project management by implementing the Scrum methodology. Organizational problem covers the ineffective Scrum meeting, lack of client participation, poor workplace, and poor document maintenance. People problem covers the ineffective communication and lack of needed skills. Technical problem covers the poor planning/working schedule and inefficient sprint planning [27].

Janeth López-Martínez [10] described scrum's adoption issues and recommended a framework consisting of people, project, process and organization [19].

Dyba and Dingsoyr [17] in their research on scrum, grouped studies into four themes that is introduction and adoption, social and human factors, perceptions on agile methods and comparative studies. In another study, it is found that the introduction of Scrum led to decrease of overtime, and developers participated in study suggested the use of Scrum in future projects. The developers were more satisfied with the product, and identified that Scrum process [2] promoted more 
communication and customer involvement. The study also described the differences in traditional and agile development on the basis of communication, organizational structure, development model and manages the quality.

According to Vlietland and van Vliet [24], scrum is the common agile method which by principle allows the IT development centers to pay attention on IT functionality. The framework is divided in seven parts, i.e. standardized emphases, littler, visit discharges, regular reflection and adjustment, cross-practical groups, consistent development and tracking, parallel testing and constant joining. The scrum framework additionally gives little direction at the alignment of working procedures between Scrum groups.

Lei et al. [11] highlighted the differences between scrum and kanban which are two dominant agile project management techniques. The research evaluates the efficiency of kanban and scrum techniques in terms of its implications for project delivery and management. Numerical analysis was performed on survey responses. The factors included in proposed framework were project scope, budget, quality, schedule, risk, and resources [19].

Misra et al. [35] discussed two success factors which are organizational and people factors. Organizational factor consists of Customer satisfaction, Commitment, Collaboration, Team Distribution and Size, Decision Time, Control, Corporate Culture and Planning. People factor consists of Learning and Training, Societal Culture, Personal Characteristics, Communication \& Negotiation and Competency.

Apart from these studies, we were unable to find studies which were relevant to our research. These papers were highly suitable to address our research questions and in finding critical factors to develop framework for applicability of agile scrum methodology.

\section{ANALYSIS AND IDENTIFICATION OF CRITICAL FACTORS}

The relevant research papers, identification of critical factors and extraction of key factors are provided in Table 1.

TABLE I. CRITICAL FACTORS IDENTIFIED FROM LITERATURE AND THEIR MAPPING ON FACTORS

\begin{tabular}{|c|c|c|}
\hline Research Paper & Critical Factors & Key Factors \\
\hline $\begin{array}{l}\text { "Critical Factors } \\
\text { for Implementing } \\
\text { the Scrum } \\
\text { Software } \\
\text { Development } \\
\text { Methodology." }\end{array}$ & $\begin{array}{l}\text { Three factors are used for } \\
\text { implementing scrum i.e. people } \\
\text { of that organization, } \\
\text { organization itself and technical } \\
\text { details. } \\
\text { Organizational Problem } \\
\checkmark \quad \text { Customer Commitment } \\
\checkmark \quad \text { Management Support } \\
\checkmark \quad \text { Tools and Technology } \\
\checkmark \quad \text { support } \\
\checkmark \text { Work place }\end{array}$ & $\begin{array}{l}\text { Organizational } \\
\text { factor }\end{array}$ \\
\hline
\end{tabular}

\begin{tabular}{|c|c|c|}
\hline \multirow[t]{2}{*}{ Research Paper } & Critical Factors & Key Factors \\
\hline & 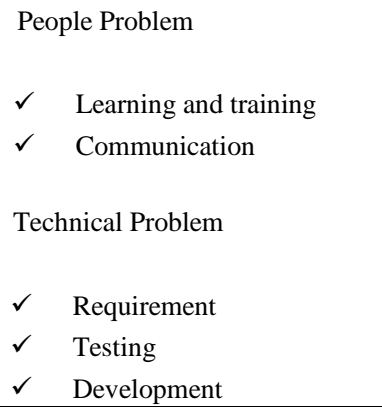 & Technical factor \\
\hline $\begin{array}{l}\text { "Problems in the } \\
\text { Adoption of } \\
\text { Agile-Scrum } \\
\text { Methodologies: A } \\
\text { Systematic } \\
\text { Literature } \\
\text { Review." }\end{array}$ & 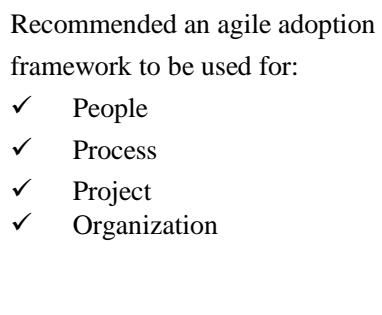 & $\begin{array}{l}\text { People factor } \\
\text { Process factor } \\
\text { Organizational } \\
\text { factor }\end{array}$ \\
\hline $\begin{array}{l}\text { "Empirical } \\
\text { Studies of Agile } \\
\text { Software } \\
\text { Development: A } \\
\text { Systematic } \\
\text { Review." }\end{array}$ & 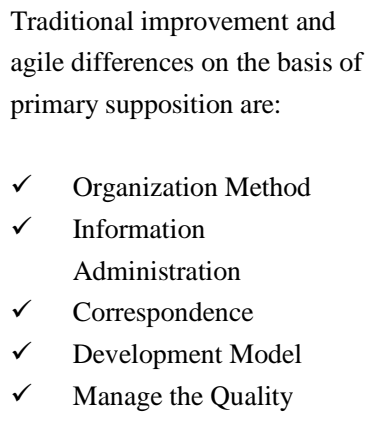 & \begin{tabular}{ll}
\multicolumn{2}{l}{ Technical factor } \\
$\checkmark$ & Information \\
& administration \\
$\checkmark$ & Development \\
& model. \\
$\checkmark$ & Manage the \\
& quality. \\
People factor \\
$\checkmark$ & Correspondence
\end{tabular} \\
\hline $\begin{array}{l}\text { "An Exploratory } \\
\text { Study on Issues } \\
\text { and Challenges of } \\
\text { Agile Software } \\
\text { Development } \\
\text { with Scrum." }\end{array}$ & 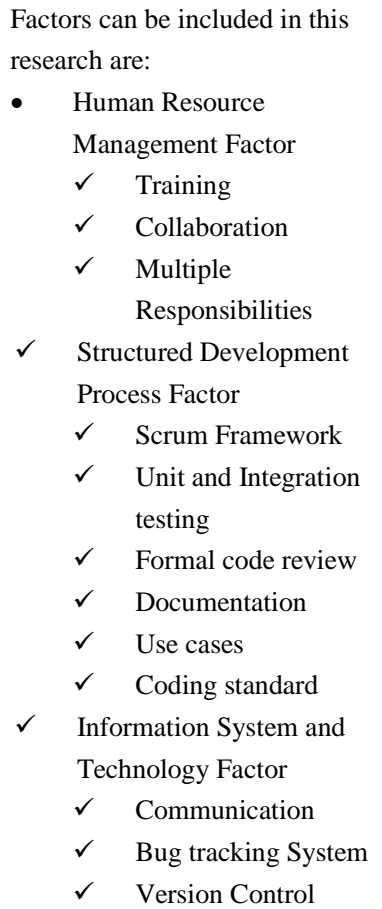 & $\begin{array}{l}\text { People factor } \\
\checkmark \quad \text { Human } \\
\text { Resource } \\
\text { Management } \\
\text { Process factor } \\
\checkmark \quad \text { Structured } \\
\text { development } \\
\text { process } \\
\text { Technical factor } \\
\checkmark \quad \text { Information } \\
\text { system and } \\
\text { technology } \\
\text { factor } \\
\text { Environmental } \\
\text { factor }\end{array}$ \\
\hline
\end{tabular}




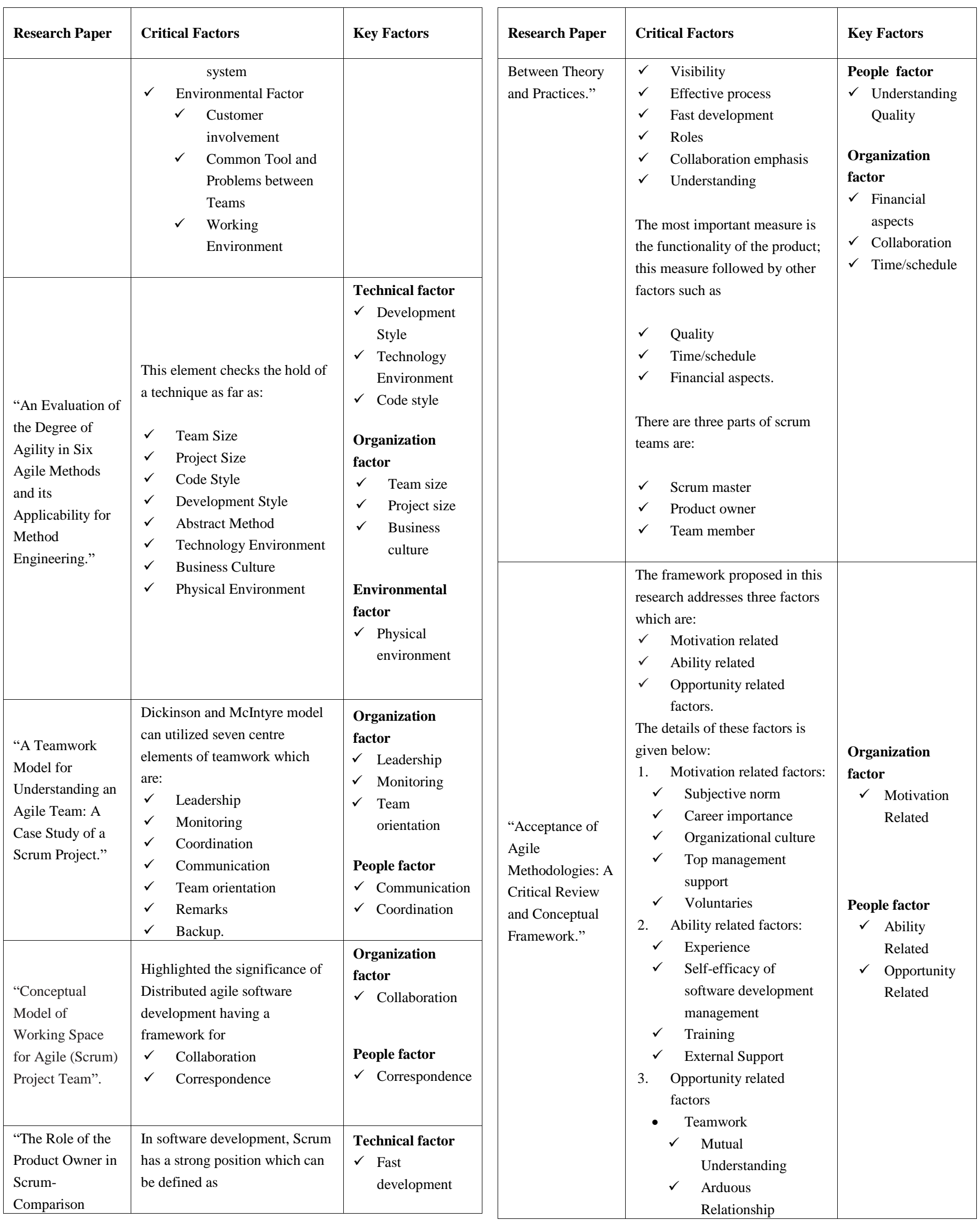




\begin{tabular}{|c|c|c|}
\hline Research Paper & Critical Factors & Key Factors \\
\hline & $\checkmark \quad$ Negotiation & \\
\hline $\begin{array}{l}\text { "Identifying } \\
\text { Some Important } \\
\text { Success Factors in } \\
\text { Adopting Agile } \\
\text { Software } \\
\text { Development } \\
\text { Practices." }\end{array}$ & 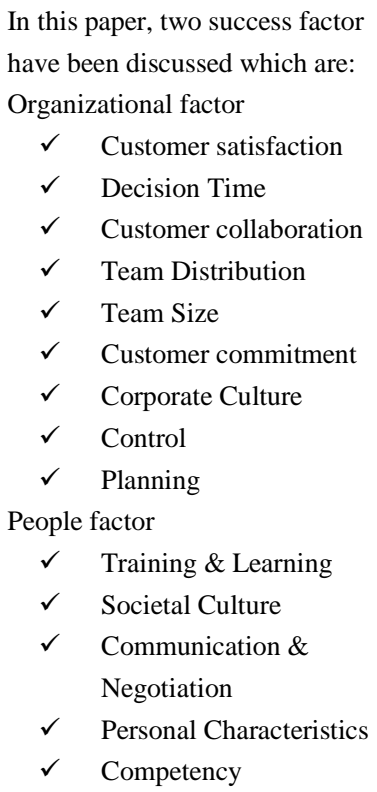 & $\begin{array}{l}\text { Organization } \\
\text { factor }\end{array}$ \\
\hline
\end{tabular}

\section{PROPOSED FRAMEWORK}

After identification of critical factors and extraction of key factors as discussed in previous section, next step was to develop framework. The key factors were analyzed in detail and four factors were selected to develop framework. The selected key factors finally included in the proposed framework which are people, organizational, technical and environmental. The proposed framework is shown in Fig. 1.

\section{A. Justification of Framework Variable}

The suitability of selected key factors is discussed below.

\section{1) People factor}

People are most significant part of any organization and project. People make decisions and work on the projects and eventually decide whether organization goals are reached or not [14], [20]. This factor is divided into four sub factors which includes: Training \& Learning, Societal Culture, Communication \& Negotiation and Personal Characteristics [28], [35].

\section{a) Personal characteristics}

Personal characteristics can be measured in terms of communication skills, honesty, collaborative attitude, motivation, eagerness to learn and sense of responsibility [35].

\section{b) Communication and negotiation}

Communication and Negotiation can be measured in terms of:
- People who work in similar time area.

- Quickly and effectively with support, customers, developers, operations, business areas and management [28].

- Communicate with others with great motivation and faith [32].

\section{c) Societal culture}

Societal culture can be measured in term of progressive attitude, generally communicative and team members with comparable social culture [35].

\section{d) Training and learning}

Training and learning can be measured with the determination of the readiness to train team members and continuously learn from one another through professionally guided negotiation and mentoring than formal trainings [35].

\section{2) Technical factor}

In this factor, there are two sub factors which are development and information administration.

\section{a) Development}

The key factors included in the development are:

- Team should create development plan of encountered.

- Problems during scrum meetings [12].

- Short, iterative and people centric development [20].

- Sustainable development is promoted throughout.

- Organization.

- Processes, approaches and easy design are practices of software development methodology [17].

\section{b) Information administration}

Information administration is about heavy documentation based on tacit knowledge management [9], [17], [20].

\section{3) Organizational factor}

In this factor, there are nine sub-factors which are Customer Satisfaction, Collaboration, Commitment, Decision Time, Corporate Culture, Team Distribution and Size, and Planning and Control [12], [35].

\section{a) Customer satisfaction}

Customer satisfaction discusses how organization provides software development projects high precedence in order to achieve customer satisfaction [35].

\section{b) Customer collaboration}

Customer Collaboration is about how customer can closely collaborate with scrum team members [28], [35]. Scrum methodology has characteristics of providing help for product development, i.e. close collaboration between the development and organization teams, approval of changing requirement, good communication, and proper documentation of the project [12], [14]. 


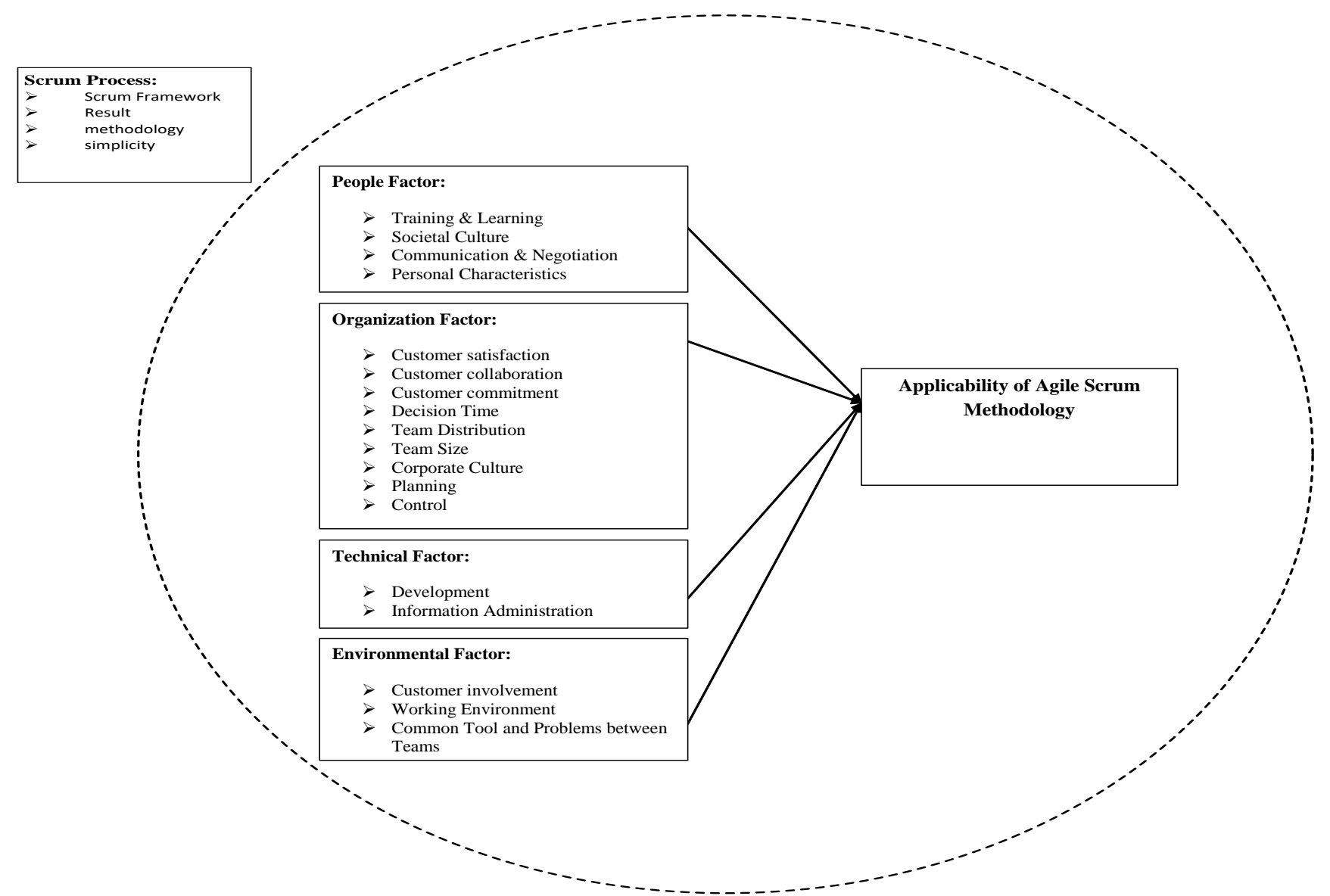

Fig. 1. Framework for applicability of agile scrum methodology.

\section{c) Customer commitment}

Customer commitment is about engagement of customers in the project [35]. A good relationship between team members and customers will help the project to run smoothly [32].

Customer commitment facilitates teams to avoid risk of delivering dissatisfying solutions.

\section{d) Decision time}

Decision time is about how to make vital projects decision quickly within short time period [35].

\section{e) Team distribution}

Team distribution is about organizational involvement in distributed international projects that will be affected by the cultural and political state [35]. How closely other team members interacting within or outside the organization are geographically located. The geographic distribution and the location of the teams are significant factors because of local politics, behavioral habit, situations and culture that greatly affect efficiency of the project team [35].

\section{f) Team size}

Team size is about the number of team member in a group which may have significant impact on the level of correspondence between team members. If there are more team members in a project then it is recommended to break them into smaller teams [29], [30], [35].

\section{g) Corporate culture}

Corporate culture defines how organization persuades immediate feedback from customers. Organizational culture can be user centric.

\section{h) Control and planning}

Control and planning discusses that software development teams relies on casual, informal and undocumented strategies and team has qualitative control [35].

\section{4) Environmnental factor}

In this factor, there are three main factors which are customer involvement, working environment and common tool and problems between teams [20]. Organization provides high quality environment to the team members [29], [30] by fulfilling needs of team member and trusting them to complete their jobs. The developer ought to work in an environment that suits them and is persistent. They require trust of other team members to accomplish high confidence level [20]. The organization ought to recognize how much documentation is suitable for each project based on the context of the development environment [20]. 
TABLE II. HYPOTHESIS TABLE

\begin{tabular}{|c|c|c|}
\hline Hypothesis & Description & Path \\
\hline $\mathrm{H} 1$ & $\begin{array}{l}\text { Training \& Learning will have a positive } \\
\text { influence over the People Factor. }\end{array}$ & $\mathrm{TL} \rightarrow \mathrm{PF}$ \\
\hline $\mathrm{H} 2$ & $\begin{array}{l}\text { Societal Culture will have a positive influence } \\
\text { over the People Factor. }\end{array}$ & $\mathrm{SC} \rightarrow \mathrm{PF}$ \\
\hline $\mathrm{H} 3$ & $\begin{array}{l}\text { Communication \& Negotiation will have a } \\
\text { positive influence over the People Factor. }\end{array}$ & $\mathrm{CN} \leftrightarrow \mathrm{PF}$ \\
\hline $\mathrm{H} 4$ & $\begin{array}{l}\text { Personal Characteristics will have a positive } \\
\text { influence over the People Factor. }\end{array}$ & $\mathrm{PC} \rightarrow \mathrm{PF}$ \\
\hline H5 & $\begin{array}{l}\text { Customer satisfaction will have a positive } \\
\text { influence over the Organizational Factor. }\end{array}$ & $\mathrm{CS} \rightarrow \mathrm{OF}$ \\
\hline H6 & $\begin{array}{l}\text { Customer collaboration will have a positive } \\
\text { influence over the Organizational Factor. }\end{array}$ & $\mathrm{CC} \rightarrow \mathrm{OF}$ \\
\hline $\mathrm{H} 7$ & $\begin{array}{l}\text { Customer commitment will have a positive } \\
\text { influence over the Organizational Factor. }\end{array}$ & $\mathrm{CC} \rightarrow \mathrm{OF}$ \\
\hline H8 & $\begin{array}{l}\text { Decision Time will have a positive influence } \\
\text { over the Organizational Factor. }\end{array}$ & $\mathrm{DT} \rightarrow \mathrm{OF}$ \\
\hline H9 & $\begin{array}{l}\text { Team Distribution will have a positive } \\
\text { influence over the Organizational Factor. }\end{array}$ & $\mathrm{TD} \rightarrow \mathrm{OF}$ \\
\hline H10 & $\begin{array}{l}\text { Team Size will have a positive influence over } \\
\text { the Organizational Factor. }\end{array}$ & $\mathrm{TS} \rightarrow \mathrm{OF}$ \\
\hline H11 & $\begin{array}{l}\text { Corporate Culture will have a positive } \\
\text { influence over the Organizational Factor. }\end{array}$ & $\mathrm{CC} \rightarrow \mathrm{OF}$ \\
\hline $\mathrm{H} 12$ & $\begin{array}{l}\text { Planning will have a positive influence over } \\
\text { the Organizational Factor. }\end{array}$ & $\mathrm{P} \rightarrow \mathrm{OF}$ \\
\hline $\mathrm{H} 13$ & $\begin{array}{l}\text { Control will have a positive influence over the } \\
\text { Organizational Factor. }\end{array}$ & $\mathrm{C} \rightarrow \mathrm{OF}$ \\
\hline H14 & $\begin{array}{l}\text { Development will have a positive influence } \\
\text { over the Technical Factor. }\end{array}$ & $\mathrm{D} \rightarrow \mathrm{TF}$ \\
\hline H15 & $\begin{array}{l}\text { Information Administration will have a } \\
\text { positive influence over the Technical Factor. }\end{array}$ & $\mathrm{IA} \rightarrow \mathrm{TF}$ \\
\hline H16 & $\begin{array}{l}\text { Customer involvement will have a positive } \\
\text { influence over the Environmental Factor. }\end{array}$ & $\mathrm{CI} \rightarrow \mathrm{EF}$ \\
\hline H17 & $\begin{array}{l}\text { Working Environment will have a positive } \\
\text { influence over the Environmental Factor. }\end{array}$ & $\mathrm{WE} \rightarrow \mathrm{EF}$ \\
\hline H18 & $\begin{array}{l}\text { Common Tool and Problems between Teams } \\
\text { will have a positive influence over the } \\
\text { Environmental Factor. }\end{array}$ & $\mathrm{CTP} \rightarrow \mathrm{EF}$ \\
\hline
\end{tabular}

a) Customer involvement

Customer involvement is very important to the success of the product. This part discusses how customers are fully involved in software development and perform tasks mutually in development team. According to agile method, customer should be part of product development [12]. Organizations ought to request customers to take part in the decision making process and devise quality approach for the execution of their project [20].

\section{b) Working environment}

Working environment means providing an environment that supports and helps team members in accomplishing their tasks [20]. An open working environment is recommended by the Scrum method which can facilitate developers to work easily, help in self-organization, and promotes communication [12].

\section{c) Common tools and problems between teams}

Common tools and problems play an important role in Environmental factor. The use of tools can help team members in reducing number of bugs in software development. Similarly, collaboration among team members can help in resolving conflicts [20].

\section{B. Research hypothesis}

The key factors selected for proposed framework were used to develop hypothesis. The derived hypotheses are provided in Table 2 .

\section{RESULTS AND DISCUSSION}

The data analysis is performed by employing statistical techniques. There are two ways to conduct data analysis through statistical methods:

\section{$\checkmark$ Descriptive Statistics \\ $\checkmark$ Inferential Statistics}

In this research, both statistical methods were used for data analysis.

\section{A. Descriptive statistics}

Descriptive statistics uses information to explain it in the form of graphs and diagrams. This method is used in this research to define the frequency of each field of survey items.

\section{1) Reliability analysis}

The common method of internal consistency [6] is to measure reliability of each factor of the framework and its correlation with other survey items. Cronbach alpha technique is used to measure the reliability of the factors/constructs [13]. SPSS 20.0 is used to perform reliability analysis [16]. According to Cronbach alpha the value greater than 0.6 is considered "Acceptable". Table 3 shows the values of Cronbach alpha.

TABLE III. FACTORS INTERNAL CONSISTENCY

\begin{tabular}{|l|l|l|l|}
\hline Factors & $\begin{array}{l}\text { Cronbach } \\
\text { Alpha } \\
\text { Value }\end{array}$ & $\begin{array}{l}\text { Cronbach alpha } \\
\text { based on } \\
\text { standardized items }\end{array}$ & $\begin{array}{l}\text { Level of } \\
\text { Reliability }\end{array}$ \\
\hline $\begin{array}{l}\text { Communication } \\
\text { \& Negotiation }\end{array}$ & 0.756 & 0.759 & $\begin{array}{l}\text { Good } \\
\text { Reliability }\end{array}$ \\
\hline $\begin{array}{l}\text { Personal } \\
\text { Characteristics }\end{array}$ & 0.811 & 0.811 & $\begin{array}{l}\text { Good } \\
\text { Reliability }\end{array}$ \\
\hline $\begin{array}{l}\text { Corporate } \\
\text { Culture }\end{array}$ & 0.675 & 0.670 & $\begin{array}{l}\text { Acceptable } \\
\text { Reliability }\end{array}$ \\
\hline Development & 0.666 & 0.660 & $\begin{array}{l}\text { Acceptable } \\
\text { Reliability }\end{array}$ \\
\hline All Items & 0.829 & 0.883 & $\begin{array}{l}\text { Good } \\
\text { Reliability }\end{array}$ \\
\hline
\end{tabular}

\section{B. Inferential statistics}

The analytical techniques are confirmatory factor analysis, hypothesis testing, and model fitting which are forms of inferential statistics. The inferential statistics is used to draw conclusions from a sample of subjects. 


\section{1) Structural equation modeling}

The structural equation modeling (SEM) describes relations between latent and observed variables in different kinds of theoretical models. Different theoretical models are tested and hypothesized in Structural Equation Modeling (SEM). For analyzing conceptualized hypotheses, SEM model involves different statistical test such as path analysis, confirmatory factor analysis, explanatory analysis and regression analysis. In this study, the model is measured through confirmatory factor analysis (CFA). AMOS 20.0 is used to perform the confirmatory factor analysis (CFA) using the Maximum likelihood estimation (MLE) process [3].

\section{a) Fitness of SEM model}

The Model Fitness shows the values of Goodness of Fit Index (GFI), Tucker-Lewis Index (TLI), CMIN/DF, Adjusted Goodness of Fit Index (AGFI), Comparative Fit Index (CFI) and Root Mean Square Error of Approximation (RMSEA). The Fitness of SEM model of data is resolved through few metrics presenting how data is very well proposed in model and does model fit to data. The model fitness indexes values are shown in Table 4.

TABLE IV. DIFFERENCE MODEL FITNESS

\begin{tabular}{|l|l|l|}
\hline Factors & My Values & Recommended Values \\
\hline TLI & 0.757 & $=>0.90$ \\
\hline GFI & 0.833 & $=>0.90$ \\
\hline CMIN/DF & 1.504 & $<=3$ \\
\hline AGFI & 0.808 & $=>0.8$ \\
\hline CFI & 0.777 & $=>0.9$ \\
\hline RMSEA & 0.049 & $<=0.08$ \\
\hline
\end{tabular}

Thus, the value of RMSEA is less than 0.08 and CMIN/DF value less than 3 means the data represent a good model fit of data.

\section{b) Testing hypotheses}

Table 5 shows the regression weights, the hypothesis testing is performed, 15 out of 18 hypotheses are significant in determining the acceptance of Framework for applicability of Agile Scrum Methodology. However, hypothesis H9 (Team Distribution), H16 (Customer Involvement), and H18 (Common Tool and Problems between Teams) were found to be insignificant.
TABLE V. REGRESSION WEIGHTS

\begin{tabular}{|c|c|c|c|}
\hline Hypothesis & AMOS Relationship & $\mathbf{P}$ & Status \\
\hline H1 & $\begin{array}{l}\text { People Factor } \rightarrow \text { Training \& } \\
\text { Learning }\end{array}$ & 0.015 & Significant \\
\hline $\mathrm{H} 2$ & $\begin{array}{l}\text { People Factor } \rightarrow \text { Societal } \\
\text { Culture }\end{array}$ & 0.015 & Significant \\
\hline $\mathrm{H} 3$ & $\begin{array}{l}\text { People Factor } \rightarrow \\
\text { Communication \& } \\
\text { Negotiation }\end{array}$ & 0.013 & Significant \\
\hline $\mathrm{H} 4$ & $\begin{array}{l}\text { People Factor } \rightarrow \text { Personal } \\
\text { Characteristics }\end{array}$ & 0.017 & Significant \\
\hline H5 & $\begin{array}{l}\text { Organizational Factor } \rightarrow \\
\text { Customer satisfaction }\end{array}$ & & \\
\hline H6 & $\begin{array}{l}\text { Organizational Factor } \rightarrow \\
\text { Customer collaboration }\end{array}$ & 0.029 & Significant \\
\hline H7 & $\begin{array}{l}\text { Organizational Factor } \rightarrow \\
\text { Customer commitment }\end{array}$ & 0.025 & Significant \\
\hline $\mathrm{H} 8$ & $\begin{array}{l}\text { Organizational Factor } \rightarrow \\
\text { Decision Time }\end{array}$ & 0.020 & Significant \\
\hline H9 & $\begin{array}{l}\text { Organizational Factor } \rightarrow \\
\text { Team Distribution }\end{array}$ & 0.058 & Not significant \\
\hline H10 & $\begin{array}{l}\text { Organizational Factor } \rightarrow \\
\text { Team Size }\end{array}$ & 0.037 & Significant \\
\hline H11 & $\begin{array}{l}\text { Organizational Factor } \rightarrow \\
\text { Corporate Culture }\end{array}$ & 0.028 & Significant \\
\hline H12 & $\begin{array}{l}\text { Organizational Factor } \rightarrow \\
\text { Planning }\end{array}$ & 0.015 & Significant \\
\hline H13 & $\begin{array}{l}\text { Organizational Factor } \rightarrow \\
\text { Control }\end{array}$ & 0.016 & Significant \\
\hline H14 & $\begin{array}{l}\text { Technical Factor } \rightarrow \\
\text { Development }\end{array}$ & 0.017 & Significant \\
\hline H15 & $\begin{array}{l}\text { Technical Factor } \rightarrow \\
\text { Information Administration }\end{array}$ & 0.014 & Significant \\
\hline H16 & $\begin{array}{l}\text { Environmental Factor } \rightarrow \\
\text { Customer involvement }\end{array}$ & 0.072 & Not Significant \\
\hline H17 & $\begin{array}{l}\text { Environmental Factor } \rightarrow \\
\text { Working Environment }\end{array}$ & 0.017 & Significant \\
\hline H18 & $\begin{array}{l}\text { Environmental Factor } \rightarrow \\
\text { Common Tool and } \\
\text { Problems between Teams }\end{array}$ & 0.070 & Not Significant \\
\hline
\end{tabular}

\section{CONCLUSION}

Agile scrum methodology is most commonly used in software industry however, framework for Agile Scrum methodology is lacking in existing literature. This research has proposed a framework for applicability of agile scrum methodology based on four factors, i.e. organizational, technical, people and environmental.

These four factors are further divided into sub factors. People factor consists of "training and learning", "personal characteristics", "communication and negotiation" and "societal culture". Organizational factor consists of customer 
collaboration, commitment, satisfaction, decision time, team distribution, size, and planning and control. Organizational factor is needed in order to perform collaboration within organization. Environmental factor consists of three sub factors, i.e. "customer involvement", "working environment" and "common tools and problems". This factor is required as customers are fully involved in software development. Technical factor consists of two sub factors, i.e. "development" and "information administration".

All these factors act as key building blocks in the proposed framework. To prove the applicability and authenticity of proposed framework, survey questions related to each factor were designed. The participants involved in survey were experts from software industry. The results from the survey were validated through reliability (Cronbach alpha) and SEM model of AMOS.

From the results, it can be concluded that the proposed framework addresses the existing gap in literature by providing a generic framework that could be used by organizations for applicability of agile scrum methodology. This research contribution opens an opportunity to conduct more extensive research in this area.

\section{REFERENCES}

[1] M. A. Ahsan. \&. Sadiq. W. Akhtar, "Scrum adoption, acceptance and implementation (a case study of barriers in Pakistan's IT industry and mandatory improvements," Industrial Engineering and Engineering Management (IE\&EM), pp. 458-461, 2010.

[2] R. Turner and B. Boehm, "Management Challenges to implemneting agile processes in traditional development organization," IEEE software, pp. 22(5), 30-39, 2005.

[3] J. Albright, "Confirmatory factor analysis using AMOS, LISREL, and MPLUS.," The Trustees of indiana University, 2008.

[4] N. Bohrweg, "Applicability of Agile Scrum within IT infrastructure projects," 2015.

[5] J. F. Blankenship, "ProAgile. NET Development with Scrum.Apress.," 2011.

[6] F. Bergeron and L. Raymond, "Managing EDI for corporate advantage: A longitudinal study," Information and managemnet, pp. 31(6),319-333, 1997.

[7] A. Begel and N. Nagappan, "Usage and perceptions of agile software development in an industrial context: An exploratory study," In Empirical Software Engineering and Measurement, pp. 255-264, 2007.

[8] N. Azizi and M.A. Taqi, "Applying Agile methodologies within the context of traditional project governance," 2015.

[9] O. A. Ambily and T. J. Malliga, "AGILE SOFTWARE DEVELOPMENTAN APPROACH TO LIGHT WEIGHT FROM HEAVY WEIGHT.," International Journal of Engineering Science and Technology, p. 3(1), 2011.

[10] J. Lopez-Martinez, R. Juarez- Ramirez, C. Huertas, S.Jimenez and C. Guerra-Garcia," Problems in the Adoption of Agile-Scrum Methodologies: A Systematic Literature Review.," In Software Engineering Research and Innovation IEEE, pp. 141-148, 2016.

[11] H.Lei, F.Ganjeizadeh, P.K. Jayachandran and P. Ozcan, "A statistical analysis of the effects of Scrum and Kanban on software development projects.," Robotics and Computer-Integrated Manufacturing,, pp. 43, 59-67, 2015.

[12] P. Sincharoenpanich, N. Chantachaimongkol, "Critical factors for implementing the Scrum software development methodology," 2013.

[13] S. Kilic, "Cronbach's alpha reliability coefficient.," Journal of Mood Disorders, pp. 6(1), 47, 2016.
[14] P. Kettunen, "Adopting key lessons from agile manufacturing to agile software product development-A comparative study.," Technovation, , pp. 29(6), 408-422, 2009.

[15] J.Han and Y. Ma, "Software Project Planning Using Agile. In Progess in Systems Engineering," Springer International Publishing., pp. 333-338, 2015.

[16] J. A.Gliem and R. R. Gliem, “ Calculating, interpreting, and reporting Cronbach's alpha reliability coefficient for Likert-type scales.," Midwest Research-to-Practice Conference in Adult, Continuing, and Community Education., 2003.

[17] T. Dyba and T. Dingsoyr, " Empirical studies of agile software development: A systematic review.," Information and software technology, pp. 50(9), 833-859., 2008.

[18] K. Conboy, B. Fitzgerald, "Toward a conceptual framework of agile methods: a study of agility in different disciplines.," ACM, pp. 37-44, 2004.

[19] T. Chow and D. B. Cao, "A survey study of critical success factors in agile software projects," Journal of systems and software, pp. 81(6), 961-971, 2008.

[20] J. J. Cho, "An exploratory study on issues and challenges of agile software development with scrum," p. 599, 2010.

[21] F. K. Chan and J.Y. Thong, "Acceptance of agile methodologies: A critical review and conceptual framework.," Decision support systems, pp. 46(4), 803-814, 2009.

[22] A. S. Campanelli and F.S. Parreiras, "Agile methods tailoring-A systematic literature review.," Journal of Systems and Software,, pp. $110,85-100,2015$

[23] J. Vlietland and H.van vliet, "Towards a governance framework for chains of Scrum teams.," Information and Software Technology, pp. 57, $52-65,2015$.

[24] J. Vlietland, R.van Solingen and H. van vliet, "Aligning codependent Scrum teams to enable fast business value delivery: A governance framework and set of intervention actions.," Journal of Systems and Software, pp. 113,, 418-429, 2016

[25] H. I.Jonasson, H.S.Sverrisdottir and H.T.Ingason, "The role of the product owner in scrum-comparison between theory and practices.," Procedia-Social and Behavioral Sciences, pp. 119, 257-267, 2014.

[26] S. Stavru, "A critical examination of recent industrial surveys on agile method usage.," Journal of Systems and Software, pp. 94, 87-97, 2014.

[27] K. Rubin, "Essential Scrum: a practical guide to the most popular agile process.," Addison-Wasley, 2012.

[28] P. Rola, D. Kuchta and D. Kopczyk, "Conceptual model of working space for Agile (Scrum) project team.," Journal of Systems and Software, , pp. 118, 49-63, 2016.

[29] A. Qumer and B. Henderson-Sellers, "An evaluation of the degree of agility in six agile methods and its applicability for method engineering," information and software technology, pp. 50(4),280-295, 2008.

[30] A. Qumer and B. Henderson-Sellers, "A framework to support the evaluation, adoption and improvement of agile methods in practice.," Journal of Systems and Software, pp. 81(11), 1899- 1919, 2008.

[31] F. J. Pino, O. Pedreira, F. Garcia, M. R. Luaces and M. Piattini, "Using Scrum to guide the execution of software process improvement in small organizations.," Journal of systems and software, pp. 83(10), 1662-1667, 2010.

[32] P. Nicolas, "Managing Global Projects Using Scrum:Challenges of Distributed Teams," 2006.

[33] S. Nerur, R. Mahapatra and G. Mangalaraj, "Challenges of migrating to agile methodologies.," Communication of the ACM, pp. 48(5), 72-78, 2005.

[34] N. B. Moe, T. Dingsoyr and T. Dyba, "A teamwork model for understanding an agile team: A case study of a Scrum project.," Information and Software Technology, pp. 52(5), 480-491, 2010.

[35] S. C. Misra, V. Kumar and U. Kumar, "Identifying some important success factors in adopting agile software development practices.," journal of systems and software, pp. 82(11), 1869-1890, 2009. 